\title{
JLEET
}

Journal of Language Education and Educational Technology

Volume 5 No. 2, 2020

e-ISSN: 2502-3306

\section{Exploring teacher's anxiety in using English and their management strategies at bilingual schools}

\author{
Mardhiyah Muchtar, La Ode Sidu Marafad, Kamaluddin
}

Halu Oleo University, Indonesia. Email : mardhiyahmuchtar@gmail.com

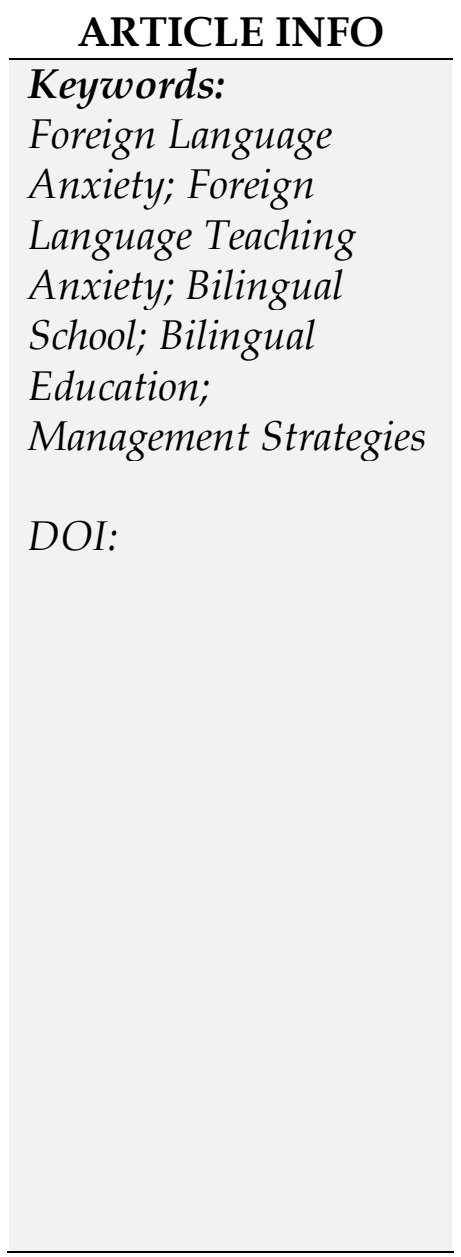

ABSTRACT

Psychological influence is a never-ending aspect that cannot be separated from language teaching and learning, and Foreign Language Teaching Anxiety is one of those psychological hindrances. This study was aimed to find out the causes of foreign language teaching anxiety (FLTA) of teachers in bilingual school, the effects, how the teachers deal with their anxieties, and school support in helping the teachers. This research employed a qualitative research, and using close-ended questionnaire, interview, and observations as sources of the data. The participants were all teachers of Lazuardi Ibnu Sina Elementary School which consists of 10 teachers (6 Homeroom Teacher and 4 Subject Teachers). The results indicated that the majority of teachers fear negative evaluations from the students and supervising teachers. It also showed that the teachers used professional, personal, and social strategies to manage their anxieties. As for the effects, most of the teachers think that teacher anxiety will affect their image in front of students and students will not get enough exposure to English. In the light of these findings, it also showed that bilingual school should provide more English Classes and English Day for their teachers and school in order to improve their English skills and manage their teaching anxieties. 


\section{INTRODUCTION}

In many researches regarding teaching and learning foreign language, our performances can be greatly affected by our psychological situation. One of the psychological obstacles in the success of English teaching is anxiety. Kralova (2016) defines that anxiety is state of mental or/and physical which is characterized by definitive symptoms like in emotion, behaviour, physical, and cognitive. There is plethora of researches regarding student's anxiety, but it is not much when it is about teacher's anxiety.

Teachers are the 'controller' of the class and they must prepare themselves to do well, managing their anxieties, and handle the unexpected situations in front of their students. If not, students will notice the 'flaws' and can be discouraged to study. Olson (in Ipek : 2016) claimed that teacher's reputation is a crucial factor in language teaching, so the concerns about this reputation would triggered some negative feelings for teachers. Teacher has own pride when teaching, so it is very important to keep their performance well in front of their students.

Meanwhile in Kendari, there are only a few schools that has English book as its delivery language. These schools used the system called bilingual education. Weiss (2016) stated that bilingual education is the form of school education where instruction and the contents are given and taught in two languages. Bilingual school use Indonesian and English in delivering learning materials by the teachers and using full-English student's books. So, the homeroom and subject teachers are expected to explain their materials in English and making strategies to make their students understand by using English.

As a non-native, teaching with bilingual education can trigger anxiety especially for teachers who has not enough English competency or low self confidence. So, the teachers here are like having two big responsibilities: teaching the learning's substance and using English well.

Based on above reasons, here are the research questions of this study:

1. What are the causes of foreign language anxiety of bilingual teachers at school?

2. What are their strategies to manage their foreign language anxiety?

3. What are the effects of teaching foreign language anxiety?

4. What are school supports to their teachers in managing foreign language anxiety?

\section{LITERATURE REVIEW}

\subsection{Definition of Anxiety}

Anxiety has become a talk for many years. Many researchers conducted studies regarding anxiety and beyond. Hewitt (in Yoon: 2012) defines that anxiety is an abnormally threatening situation that will cause some noticeable physical symptoms like sweating a lot, increased pulse, feeling tense, etc and will make a person questions himself for their inabilities to work on situations.

The definitive causes of 'anxiety' itself can be very complex, because it can be affected by psychological, biological, socials, and others. The reason of those anxieties may vary in regards of place, situations, gender, personality trait, etc. 
Sarason (in Tum: 2012) defined that there are some noticeable characteristics of anxiety in general. Here is the list:

1. The situation is quite threatening or difficult

2. The individual involves is feeling down and incapable being in this situation

3. The individual will be shadowed by negative thinking of not being able to stand cope with those kinds of situations

4. The individual would feel unconfident and not sure about his/her cognitive skills and feeling inferior

5. It would make the individual thinks that he/she is a failure in front of others

It can be seen that anxiety itself is negative sensation which is triggered by a difficult/threatening situation that will make an individual lost his/her confidence and start to think of negative results.

\subsection{Language Anxiety}

Language anxiety is not a new thing in education world, because it's also most important part that will decide the success of a language study. Young in Tran (2015) proposed that language anxiety is a psychological construct which is really complex and requires researches with varied approaches and perspectives. Many researches regarding anxiety came from different perspectives. Language anxiety is negative feeling which is triggered by unwanted situations when we want to use a particular language.

Cubukcu (in Yoon: 2012) divided anxiety which is focuses on language anxieties; they are cognitive and somatic anxiety. Cognitive anxiety is mental aspect which is highly affected by previous negative feelings like worrying about people eyes, harsh judgment, fear of failure etc in learning/using a language. Meanwhile somatic anxiety is physical effects that will emerge after feeling those negative emotions. Keaten (in Tuyen: 2017) agreed that language anxiety is a complex or complicated situation of feelings which is triggered by various causes. She further elaborated that it refers for the feeling of uneasiness, worry, nervousness and apprehension experienced by non-native speakers when learning or using a second or foreign language".

\subsubsection{Foreign Language Teaching Anxiety (FLTA)}

Alrabai (2015) stated that foreign language anxiety is considered more to psychological construct (based from individual identity) rather than linguistic construct. The theory of Foreign Language Anxiety was first proposed by Horwitz in 1996, and his study about foreign language anxiety still be used till now. He claimed that non-native language teacher sometimes experience some uneasiness and inadequacy in teaching target language. He further stated that all non-native teachers will always in state of 'learner' no matter their levels are. So, it means that there is no non-native teacher whom never feels anxious/ worried at all when he/she uses English. Yoon (2012) also stated that even a non native teacher has a high English skills, he/she would still have some uncomfortable moments whenever they use English. 


\subsubsection{Possible Causes of Foreign Language Teaching Anxiety}

In similar line, Jackson (2010) claims that foreign language anxiety a complicated phenomenon in target-language medium classrooms, as it is provoked by a complex set of cultural, linguistic, psychological, and social factors. Philip (in Klanrit \& Sroinam : 2012) also argues that anxiety which is indicates by strong emotions will be likely can hinder persons' performance in speaking.

Moreover, Horwitz (1996) later made some categories of anxiety provoking causes of teaching foreign language, they are : Fear of Making Mistakes, Teaching a Particular Skill, Teaching Students at Particular Language Level, and Fear of Failure. Meanwhile, based on Kim and Kim (2004), teaching foreign language anxiety causes can be categorized in 4 main factors, they are :

1. Limited knowledge (LK). Refers to the general knowledge about the language itself

2. Limited language skills (LS). Refers to inadequate competency in particular skills. For example, a person can speak English well but feeling difficult in teaching grammar.

3. Teaching situations (TS). Refers to when something happens in the middle of teaching like when the class is too crowded, miscellaneous students, etc

4. Fear of negative evaluations (NE). Refers to state of being afraid to be observed negatively by students, peer teachers, or senior teachers because of doing something wrong.

\subsubsection{The Effects of Foreign Language Teaching Anxiety on English Learning}

In case of anxiety in teaching foreign language, there are a lot cases which shows that teacher's anxiety would give shortcomings on a success of foreign language class. Anxiety can be positive if it is in very low level just like what stated by Oxford in Merc (2011). Anxiety can give positive effects when it is kind of facilitative anxiety, which is anxiety that affects a person positively. So, the person will feel motivated to do better instead of be negative or giving up. In contrast, debilitative affects a person negatively. It will make a person feels negative about him/herself and have bad expectation for his/her next performance. The study from Machida (2011) about teaching English in Japanese Elementary classroom stated that $90,7 \%$ of teachers are anxious to teach English and 77,4 $\%$ of teachers are anxious about their own English proficiency. The participants stated that the students will not get what the teacher mean if the teachers didn't master English well, and it will affect students' English competence too.

Another study conducted by Merc (2011) stated that teachers feel anxious about new class and whether he/she will perform well in front of the students. Some of them also stated that they're afraid that their performance won't be good enough in front of supervisor teachers, and it will affect her/his assessment in teaching. In addition, Mustafa (2018) in his study about using English as teaching medium in kindergarten stated that some teachers thinks that low motivation and high anxiety in teacher will make teacher not using English well and they are afraid whether they can teach the students or not. To support that statement, Yoon (2012) in his study about anxiety of non-native EFL teachers also claimed that foreign language anxiety will affects not only speaking aspects of 
teaches, but also the success of learning procedures in class directly, and it will affect the teacher's image in front of the students.

\subsubsection{The Possible Strategies in Managing Foreign Language Teaching Anxiety.}

As a language teacher, we must have some good strategies of teaching in order to maintain a good image in front of the class and give best influences to the students. Luo \& $\mathrm{Xu}$ (2016) suggested in their study that in order to have well-balanced and comfortable class situation, teacher should work it up with the students to manage the anxiety too. Murray and Harvey (1999) developed some categories of coping strategies of Teaching Foreign Language Anxiety. Here they are :

1. Personal Strategies. There are 5 sub-categories in this category :

- Cognitive Strategies: Including Positive thinking, humour, blocking negative image, making a realistic expectations

- Physical Strategies: Active (doing physical things like walking a bit, holding something, or doing activities with students) and Passive (reading, listening music, watching something)

- Behavioural Strategies: Engaging in routines

- Emotional Strategies: Ability to accept that human can make failures

- Rational Strategies: Separating time as teacher and as a human

2. Professional Strategies

- Knowledge of Curriculum: Includes knowing what to teach, the structure, organization, and culture of the school

- Self Management Skills: Ability to do planning and preparing things before lesson and ability to preparing what do to when faced in difficult situation

- Professional Qualities:, Making varied learning strategies for students, adapting and try to have good communication with the students, and rewarding the students.

3. Social Strategies

- Personal Discussion: Sharing problems with close social supports like family and friends

- Involvement in Social Event: Doing activities and be active in front of people

4. Institutional Strategies

- Support from Other Teachers and Principal

\subsection{The Concept of Bilingual Education}

Most of the people know that bilingual literally means two languages. May (2017) stated that bilingual education is instruction in two languages (but emphasis is in the first language) and the use of those two languages as mediums of instruction for any part or, or all, of the school curriculum. Baker (in May: 2017) whom explained that the school can be said as a bilingual education if they use more than one languages to teach content (e.g Science, Math, Social Studies, Humanities, etc) rather than just being taught as language subject. 
In Indonesia, the development of bilingual education is growing quite fast. Wuli (2012) said that the year 2006 is the milestone of the bilingual education in Indonesia. The Ministry of National Education established a programme known as Rintisan Sekolah Bertaraf Internasional (translated as The Pioneer International Standard Schools). The initial function of bilingual education in Indonesia is to provide language exposure for students to develop English and prepare Indonesia for the migration of international resources and improve access to international market (Direktorat Jenderal Pendidikan Dasar Kementerian Pendidikan Nasional in Wuli: 2012). Thus, there are several problems in doing bilingual education such as the difficulties in explaining the materials in English, the materials in books are too difficult for students, and lack of help from school and governments. At 2013, Rintisan Sekolah Bertaraf Internasional program in state schools was terminated because of several problems above. Only some private schools still be able to apply the bilingual program. Now in 2019, the trend of bilingual education comes back to private schools. In big cities, there are a lot of private schools which applied bilingual program and has some international students there.

\section{METHODS}

This study used qualitative design to study about Foreign Language Teaching Anxiety as one of social phenomena in education. The participants of this study are all teacher of Lazuardi Ibnu Sina Elementary School which consists of 10 teachers. The researcher conducted this study from late November to Early December 2019. The data are collected by giving close-ended questionnaire, interview, and class observations for all teachers. In order to analyze the data, the researcher took some steps below:

1. First, the researcher took the result of close-ended questionnaire and write down the frequency of each answer.

2. Second, the researcher wrote some important notes and conclusion after observing how each teacher teach and in English Class

3. Next, the researcher analyzed the result of close-ended questionnaire, observation, and in-depth interview by using Content Analysis. So, the researcher wrote down some similarities in each data and described it into final conclusions. The causes of anxiety would be categorized based on Teaching Foreign Language Causes by Kim a\& Kim (2004), while the for management strategies would be categorized based on category developed by Murray and Harvey (1999)

4. Last, the researcher connected every result of close-ended questionnaire, observations and in-depth interview of every teacher, and made the final conclusion of these findings. 


\section{FINDINGS AND DISCUSSION}

\subsection{Findings}

This section is divided into three sections: Result of Close Ended Questionnaire, Result of Observations, and Result of Interview.

\subsubsection{Result of Close Ended Questionnaire}

This close-ended questionnaire consists of 5 general questions related to Teaching Foreign Language Anxiety (TFAL) in bilingual school (in this case is Lazuardi Ibnu Sina Elementary School). This close-ended questionnaire was given before the researcher doing the observations and interviews. This questionnaire was in Bahasa Indonesia to make it easier to understand and answer.

Here are the result of close-ended questionnaire, Q1 (Their English competency), Q2 (How often do they feel nervous/ anxious at school), Q3 (The biggest cause of anxiety), Q4 (Whether they have strategy in managing anxiety, and Q5 (Whether the school support them in managing anxiety or not) :

\begin{tabular}{|l|l|l|l|l|l|}
\hline Participant & \multicolumn{1}{|c|}{ Q1 } & \multicolumn{1}{c|}{ Q2 } & \multicolumn{1}{c|}{ Q3 } & \multicolumn{1}{c|}{ Q4 } & \multicolumn{1}{c|}{ Q5 } \\
\hline Participant A & Low & Often & Class Situation & I Have & Yes \\
\hline Participant B & Good & Sometimes & Class Situation & I Have & Yes \\
\hline Participant C & Good & Sometimes & Other Teachers & I Have & Yes \\
\hline Participant D & Enough & Seldom & Other: Native Speaker & I Have & Yes \\
\hline Participant E & Low & Often & Learning Materials & I Have & Yes \\
\hline Participant F & Good & Seldom & Other Teachers & I Have & Yes \\
\hline Participant G & Low & Sometimes & Other Teachers & I Have & Yes \\
\hline Participant H & Enough & Sometimes & Class Situation & I Have & Yes \\
\hline Participant I & Good & Sometimes & Class Situation & I Have & Yes \\
\hline Participant J & Enough & Sometimes & Class Situation & I Have & Yes \\
\hline
\end{tabular}

The result of Q1 showed that 4 out 10 stated they have Good English skills, 3 teachers stated they have Enough English skills, and the other 3 stated that they're in Low category. No teachers stated that they are in Very Good or Very Low category. It means that the teachers here have varied level of English skills.

For Q2, majority (6 out of 10) teachers think they just feel nervous/ anxious sometimes. Two of them stated that they seldom feel nervous/ anxious. The last two stated that they Often feel nervous/ anxious.

For Q3, 5 out 10 stated that Class Situation is their biggest source of anxiety; the other 2 stated that Other Teachers is their source of anxiety. Two teachers have different statement which is about the native speaker and difficult learning materials.

For Q4 and Q5, all teachers stated that they have strategies in managing anxiety and school supports them to manage anxiety. 


\subsubsection{Results of Observation Classroom Observations}

After observing each class of each teacher, the researcher can conclude that all of the teachers feel unbothered by the researcher. Also, just two of them comfortably use English in their classes; the others are using English and Bahasa like 50:50. Last, some of teachers use more Bahasa than English in their class for several reasons like because students were confused and ask many questions or when he/she warned the students.

\section{English Class for Teachers Observation}

The researcher observed two meetings of this class. The first one about personal questions games of teachers, so each teacher guessing the personal questions like favorite foods, thing they hate, etc. In this class, each teacher got chance to speak up. Experienced teacher can answer the questions comfortably and easily, while the newly-recruited teacher and some subject teachers speak English and Indonesia with the help of English tutor. Still, all of the teachers are doing it diligently. The second meeting was about correcting and evaluating English instructions in this school. The English tutor asked the teachers what are the instructions they used in class and what are the problems in using instructions. In this section, there wasn't much speaking up activity, so only the active ones are those who have good English skills or majoring in English Education.

Based on these observations, it showed that experienced teachers are more relaxed and active in using English, meanwhile newly-recruited teacher and subject teachers seemed not really active in speaking but still follow the activities diligently. Subject teachers were also welcomed to be corrected and guided by the controller. But some subject teachers only speak very little and seemed shy to speak.

\subsubsection{Results of Interview}

In this section, the teachers were asked to answer 5 questions to answer the research questions. Here are the result:

Q1 : Do you experience any kinds of anxiety or nervousness while using English in this school? How often?

For Q1, Majority of the teachers stated that they just feel nervous/ anxious sometimes. They also stated that in the past they used to feel that often, but right now they just feel that sometimes. Just 2 participants stated that they often feel nervous/ anxious. These answers came from one newly-recruited teacher, and the other one was a subject teacher. The last two answers stated that they seldom feel nervous/ anxious. These answers came from the experience teachers of this school.

Iya pernah cukup sering hehee (yes, I feel that often hehee)

iya.. tentunya khawatir sama apa gugup juga pada saat menggunakan bahasa inggris di lingkungan sekolah, apalagi pada saat mengajar. Pernah tapi tidak keseringan juga 
(yes.. of course nervous and anxious when we're using English in school too, especially when I am teaching. I sometimes feel it but not that often)

Q2: What kind of situations that make you anxious or nervous while using English in this school?

The participants stated that class situation and the students is their biggest cause of anxiety. Some stated that they're afraid of making mistakes in front of the students. There are three participants stated that the other teacher was the biggest reason of their anxiety. They stated that they're getting anxious when observed by the other teachers. Meanwhile, two of the teachers expressed that she felt nervous when she doesn't know the meaning of words in the middle of teaching.

Seperti umpamanya anak-anak SD bertanya kepada saya pakai bahasa Inggris saya tidak mau menjawab bagaimana... takutnya ee jawaban saya salah

(For example when elementary students asked me in English and I don't know how to respond, I feel.. I am afraid that I will give wrong answer)

Biasa situasi itu lebih kepada jika ada guru-guru lain pada saat proses pembelajaran terus eye contact dengan saya pada saat mengajar itu situasi gugupnya dari situ juga)

(The situation is when there are other teachers coming in the middle of learning process and doing eye contact with me when I am teaching, that's also the cause of anxiety)

Kalau saya kan saya agak kurang kata-kata bahasa Inggrisnya begitu, jadi agak susah juga disaat mengajar tiba-tiba ada kata yang saya kurang tau artinya atau maksudnya, jadi agak gugup juga pas mengajar

(I don't have good English vocabularies, so it is difficult when in the middle of studying I found unknown words or unknown meaning, so it makes me nervous too)

Q3: What do you think about the negative effect of anxiety or nervousness while using English in this school?

Anak-anak akan ketawa kalau salah.. ii bu guru salah begitu. Kalau guru-gurunya yang lainnya sih anggapnya lucu

(The students will laugh at us if we're wrong.. teacher, that is wrong, like that. But the other teachers think it is funny)

Hmm.. biasa kalau dampak negatifnya agak kaku ya gimana ya agak kelihatan gak menguasai materi atau apalah ..)

(Hmm.. usually the negative impact is the teacher will be looking stiff or what can I say .. looks unprepared or whatever) 
From result of interview, 9 of teachers stated that the negative impact would be more to teacher's performances in front of the students. There are 4 statements about mispronouncing words, 2 statements about using less English in class, 5 statements about making students confused and didn't fully understand the materials, 1 statement about looking unnatural or stiff when teaching. Only one teacher stated that it will affect his English performance in general.

Q4: What did you do to manage anxiety when you use English?

yang paling penting kita artikan dulu apa-apa yang belum diketahui. Kedua saya biasa membuat catatan-catatan kecil

(...the most important thing that I usually do is translating words that I didn't know yet. Then, I usually make small notes about a process in Science subject, I made some small notes in my notebook)

Kalau saya mungkin guru itu harus baca-baca dulu bukunya dan siapkan memang peraganya

(For me the first one is teacher should read the subject books and the kit)

Biasanya sebelum mengajar itu tulis-tulis memang apa yang mau diajarkan atau saya bertanya ke guru English kalau saya tidak tahu

(Before I teach, I usually write down the unknown words or words related to teaching or asking the English teachers about something I didn't know)

In interview results, it showed that majority of teachers (6 out of 10) stated that in order to overcome those anxieties, they need to prepare themselves like reading the materials before lesson, listing all the related vocabularies, and making notes about unknown things. Meanwhile, one teacher stated that holding something (pen) would and talking/joking to the students decrease her anxiety, and the other one also stated that she played a game or music in her class if she feels anxious.

Hmm contoh sederhana mungkin dengan memegang sesuatu barang misalnya spidol itu salah satu cara mengurangi rasa gugup, terus juga apa ya lebih berusaha mengajak anakanak ngobrol bercanda begitu atau belajar sambil bermain jadi gak terlalu tegang bawaannya

(Hmm the example is holding a thing like marker, is one of the way to decrease that nervous feeling. Then I tried to talk and joking with my students or playing while studying so it is not really nervous)

The last two have different answer than the previous teachers. He stated that he would keep cool and comfortable and asked the other teachers/ students the unknown words. And the other one said that she just has to be relaxed and sit, and then her nervous/anxious feelings would fade away. 
kalau supaya nda gugup itu. biasanya saya tetap stay cool kalau ada teman disitu saya bertanya apa artinya.. karena harus ditau artinya.. atau di kelas saya tinggal lempar pertanyaan ke siswa yang pintar begitu.. atau meminta siswa buka kamus)

(To get rid of anxiety.. usually I keep relaxed, if the teachers beside me I will ask what is the meaning, because I need to know the meaning, while in class I will ask a smart student or asking the students to open their dictionary)

Sebenarnya tidak ada hanya memang rasa tiba-tiba gugup nanti hilang sendiri jika kita tenangkan diri duduk begitu

(Actually I just do nothing, I think that nervous/anxious feeling will fade away if we just relax ourselves or sit, like that)

Q5 : What can the school do to overcome the teacher's nervousness / anxiety in using English in school?

kalau yang sudah dilakukan sekolah, kan dalam setiap minggu ada English class ya seperti itu untuk guru, jadi setiap seminggu 2 kali itu kegiatan di sekolah itu harus menggunakan bahasa inggris, ya itu upayanya supaya kita punya kemampuan bisa meningkat. Kadang kita lupa karena adanya English day akhirnya kosakata yang kita lupa bisa kita ingat kembali

(In this school, every week there is an English class for teachers, and twice a week there is an English Day, that's the efforts so that our English skills will get better. Sometimes we forget our that English Day so that we forget some of the vocabularies.

Oo di sekolah ini sudah diterapkan di hari selasa dan kamis penggunaan English day, jadi dari pagi dari jam setengah 7 sampai setengah 2 itu para guru wajib menggunakan bahasa inggris, jadi itu sebagai model pembelajaran juga untuk kami semua agar lebih memperlancar lagi bahasa inggris nya dan tidak gugup lagi

(Oo in our school, every Tuesday and Thursday there is an English Day, from 06.30 a.m till 01.30 p.m, so it is a way of learning for us teachers to be more fluent in speaking English and not nervous anymore)

The result showed that the school had already supports the teachers in overcoming anxiety. The way is by doing English Class for Teachers (and it is taught by an English teacher in Lazuardi) once a week and doing English Day twice a week. Seven of ten teachers explained about English Class and English Day. Three teachers complimented the use of English Class. One teacher hoped that English Class should be done more often, whereas one teacher stated that it'll be good if all teachers and students in Lazuardi doing the English Day diligently and be more active. 
Moreover, one teacher said that school also support and help he teacher in becoming MC for some school events that use English. He thinks that it will help teachers overcoming their anxieties. The other also stated that it is good that school give them freedom in managing classroom activities as long as it fulfils the aim of the study.

\subsection{Discussion}

This study was conducted in Lazuardi Ibnu Sina Elementary School which is one of bilingual school in Sulawesi Tenggara. In this study, the researcher gave close-ended questionnaire and interview to all of the teachers and doing observations in classrooms. In this discussion section, the findings would be explained more detailed and supported with similar data.

\subsubsection{Causes of Teaching Foreign Language Anxiety}

\section{Table 4.1}

Causes of Foreign Language Teaching Anxiety

\begin{tabular}{|l|l|l|}
\hline No. & Interviewees & \multicolumn{1}{c|}{ Causes of Anxiety } \\
\hline 1. & Participant A & - Afraid of making mistakes while speaking in front of students \\
2. & Participant B & - Limited vocabulary \\
3. & Participant C & - Being observed by the other teachers \\
4. & Participant D & - Wrong pronunciation \\
5. & Participant E & - Difficult learning material \\
6. & Participant F & - Being observed by the other teachers \\
7. & Participant G & - Afraid of making mistakes in front of other teachers \\
8. & Participant H & - Wrong Pronunciation \\
9. & Participant I & - Afraid of making mistakes in front of students \\
10. & Participant J & - Very limited vocabulary \\
\hline
\end{tabular}

In this table, we can see that half of the participants ( 5 out 10) stated that source of their anxiety is fear of negative evaluations (NE). Those negative evaluations come from different sources too. Three of the participants expressed that they afraid of negative opinions from their students if they make mistakes. For example from Participant A, she stated that she's afraid that she'll make mistakes in front of students and students would point it out directly. It is in line with teacher's statement like: "Seperti umpamanya anak-anak SD bertanya kepada saya pakai bahasa Inggris saya tidak mau menjawab bagaimana... takutnya ee jawaban saya salah". Meanwhile, the other two participants expressed that they fear of negative evaluations from the other teachers. Participant $C$ stated that he will feel nervous 
if he suddenly making eye contacts with other teachers in the middle of teaching. He expressed "Biasa situasi itu lebih kepada jika ada guru-guru lain pada saat proses pembelajaran terus eye contact dengan saya pada saat mengajar itu situasi gugupnya dari situ juga" and Participant $\mathrm{F}$ said that she used to be very nervous when the observing senior teacher came into the class "Hmm awalnya seperti saat mengajar dengan dipantau hehee apalagi saat awal-awal mengajar dengan guru-guru yang melihat keadaan, disitu saya merasa gugup. It is in line with Tum (2012) statement about they're afraid to get negatively evaluated by their superior peers and appearing foolish in front of them. Ipek (2016) also claimed that teacher's anxiety can be triggered if they're being compared to other teachers. So, it indicated teachers can feel that negative evaluations by the students, not just by supervising/senior teachers.

Next, statements from three teachers are included in Language Knowledge (LK) factors. Two of them stated that they have limited vocabulary which make them nervous to use English, and the other one said that difficult teaching materials makes her anxious. Horwitz (1996) stated that teachers usually worried about their proficiency and questions their capacities in teaching with speaking English, and it make them anxious. Ozturk (2016) also expressed that the teachers got anxious if they don't know the pronunciation or when the students ask the meaning of a word. It showed on statement like this "Kadang kalau kalau gugup itu kadang dari misalnya kita tidak tau artinya dari bahasa inggris itu, atau kalaupun tau artinya misalnya kita tidak tau apa maksudnya, "

The last two teachers chose Wrong Pronunciation as their source of anxieties, which is included in language skills (LS). One stated that she feels anxious if she mispronounces something in front of students while the other one said that he feels anxious if he mispronounces something in front of the other superior teachers, just like in statement " ... kalau tiba-tiba hening terus pronunciation itu jelek atau gimana itu aduh bikin menimbulkan pertanyaan baru

\subsubsection{The Explanations about Negative Effects of Teacher Foreign Language Anxiety}

For this section, teachers were interviewed to explain what they think about negative effects of teaching foreign language anxiety. Teachers here give one or more answers about this question. There are four statements regarding teacher's anxiety which can make students confused in learning, such as: Participant D expressed that the students will be confused if the instructions are unclear (example in Science subject) because of anxiety, and at the end the materials can't be delivered well. Participant $\mathrm{H}$ stated mispronunciation that cause by anxiety will make students confused and asking which one is wrong/correct, and they can point that mistakes too. Ozturk (2016) said that one of the effects of anxiety is students become judgmental and point out/laugh at teacher's mistakes, which is not a good a situation for the teachers.

Several statements also expressed that anxiety will make their pronunciation unclear or incorrect and using wrong vocabulary. Participant E stated that feeling anxious will make the students look weirdly at the teacher and confuse them. Also, It will affect teacher's image in front of the students (looking unprepared or blank), and students can 
obviously noticed that too. Just like statement form Participant $C$, he said that anxiety will make teachers look unprepared or blank, and it will make the student confused. Most importantly, teaching messages can't be delivered well to students and the exposure of English would be reduced too. Participant B stated that if she's anxious, she will just speak in Indonesia to make students more understand, but it will reduce the usage of English in class. One teacher also stated that his English skill won't be improved if he keeps anxious/ worried in using English.

\subsubsection{The Classification of Teacher's Strategies in Managing Foreign Language Anxiety}

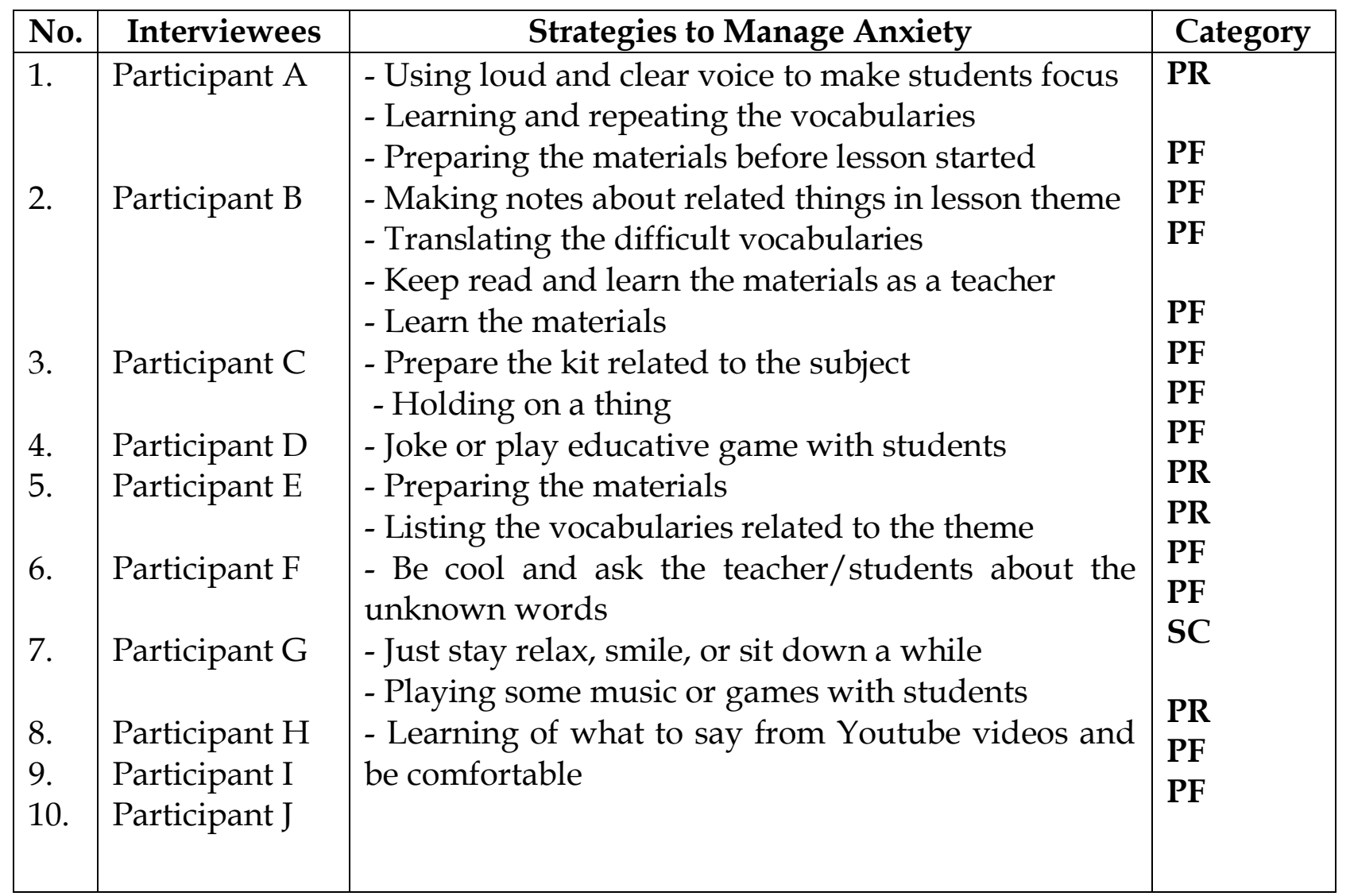

Regarding to the table of strategies to manage anxiety, it showed that most of the teacher has more than one strategy in managing their teaching anxiety. Most of them are categorized as Personal Strategies (PF). To be more specific, majority of the teachers stated that be prepared and reading the materials before lesson is the ultimate strategies to manage upcoming anxiety.

Next, the teachers also expressed that strategy when teaching in the class is by doing various methods like using loud clear voice to catch the attention, be relaxed, holding something, and talk humorously with the students to ease the tense situation. One statement from Participant $\mathrm{H}$ was slightly different. She said that to manage the anxiety, she just needs to relax or sit and the anxiety will fade away. In addition, Participant I 
stated that 'be prepared' and 'tried to be comfortable' are the ways to reduce anxiety. After all, these all are included in Personal Strategies (PR).

In statement one we see that one teacher said "speaking loudly" is the way to boost her confidence and manage her anxiety. Besides, Participant E revealed that she holds a marker when she feels anxious/ nervous, and also talk friendly with the students. Besides, one teacher also uses music to feel more comfortable or playing games with the students. Pasaribu (2018) also stated that using games in learning is one of the favourable methods that will ease the teacher and students, and learning objectives would be achieved comfortably. So, playing music, games, and joking are also the way to ease the tension between teacher and students in classroom.

The only one statement of category Social Strategy (SR) comes from Participant G who stated that when he feels anxious about not knowing the meaning of words, he'll just ask the nearest teachers there or when he is the class, he'll just ask the smart students or tell them to look it up in dictionary.

In conclusion, the most used strategy to manage the teaching foreign language anxiety in Lazuardi Ibnu Sina Elementary School Kendari is Professional Strategy (PR), with the emergence of 11 statements that can be categorized as PR. These also showed the importance of being prepared and studying the materials for teachers to minimize their anxiety.

\subsubsection{The Explanation of School Support to Manage Teacher's Anxiety}

In case of school supports for teachers, majority (7 out 10) of the teachers mentioned English Day and English Class for Teachers or both. It is stated that the English Day was done twice a week and English Class once a week with an English teacher as a tutor. Niskodubov (2015) in his study about English course for adult learners claimed that doing course with suitable structures is an effective way to acquire the high level of language learning for adults. Ozturk (2016) also suggested that courses or training for non-native language teachers should be conducted more accurately in order to improve vocabularies and other skills. They all hoped that school should encourage the teacher to be more active in English Class for Teachers and be more discipline to speak in English in English Day. Besides, one teacher stated that school asked the teachers one by one to be MC for school event that using English. He said that it helped the teacher to practice public speaking and managing their anxiety. Also, one teacher expressed that school should encourages the new teachers to learn and ask senior teachers if they need help. The last one stated that school already gave freedom for each teacher to build the class atmosphere and using any creative methods as long as it is fulfils the aim of the study. In conclusion, the major supports from school are English Class for Teachers and English Day for all students and teachers. Teachers hoped that English Class for Teachers and English Day should be done more diligently and discipline. 


\section{CONCLUSION}

In regards of this study and results of findings analysis and discussions, it can be concluded that:

1. There are total 5 of 10 teacher expressed that anxiety can be triggered by fear of negative evaluations by both students and other teachers. In terms of language knowledge, 3 teachers expressed that they have limited vocabulary that make them anxious. Last, 2 teachers are anxious if they mispronounce something in front of both students and other teachers

2. To manage teaching foreign language anxiety, participants expressed that they used these strategies: Professional Strategies (Preparing and studying the materials, listing the related vocabularies, and using internet). There are 11 statements that expressing the use of Professional Strategies. For Personal strategies (using loud/clear voice, holding something, talk humorously with students, playing games and music), there are 5 statements. The last one Social Strategy (Asking the other teachers and ask to students to look up to dictionary) was expressed by 1 statement.

3. Majority of the teachers think that's foreign language anxiety will affect teacher's image in front of the students (example like looking unprepared, not knowing the meaning of words, and mispronunciation), making students confused, and English exposure for students will be reduced

4. Based on interview transcript, all teachers stated that the school already gave all of teachers and English Class For Teachers once a week and English Day twice a week in terms of school's supports. Majority of the teachers think it is good but it should be done more often, more diligently, and more discipline. The other statements are asking the teacher to be an MC in English and given freedom to create the class situation as long as it fulfils the aim of study.

\section{References}

Alrabai, Fakieh. 2014. The Influence Of Teachers' Anxiety-Reducing Strategies On Learners' Foreign Language Anxiety. Innovation in Language Learning and Teaching, 8(1). Kralova, Zdena. 2016. Foreign Language Anxiety. Nitra, Slovakia: Univerzita Konštantina Filozofa Nitre.

Hismanoglu, Murat. 2013. Foreign language anxiety of English language teacher candidates: A sample from Turkey. Procedia - Social and Behavioral Sciences 93 ( 2013 ) 930 - 937

Horwitz, E. K. 1996. Even Teachers Get The Blues: Recognizing and Alleviating teachers' Feelings of Foreign Language Anxiety. Foreign Language Annals, 29, 365-372.

Ipek, Hulya. 2016. A Qualitative Study on Foreign Language Teaching Anxiety. - Journal of Qualitative Research in Education, 4(3), 92-105

Jackson, Jane. 2010. Reticence in Chinese EFL Students at Varied Proficiency Levels. Reticence in Chinese EFL Students at Varied Proficiency Levels. TESL Canada Journal/Revue TESL Du Canada 65 VOL. 26, NO 2

Kim, S. Y., \& Kim, J. H. 2004. When The Learner Becomes A Teacher: Foreign Language Teaching Anxiety As An Occupational Hazard. English Teaching, 59(1), 165-186. 
Klanrit P. \& Sroinam R. 2012. EFL Teacher's Anxiety in Using English in Teaching in the Language Classroom. International Journal of Social Science and Humanity Vol. 2, No. 6, November 2012

Murray-Harvey, R., Slee, P. T., Lawson, M. J., Silins, H. C., Banfield, G., \& Russell, A. (1999). Under Stress: The Concerns and Coping Strategies of Teacher Education Students. Third International Conference on Teacher Education, Beit Berl College, Israel.

Niskidubov, Gavriil. 2015. English Language Courses for Adult Learners in Russia. XV International Conference "Linguistic and Cultural Studies: Traditions and Innovations", LKTI 2015, 9-11 November 2015, Tomsk, Russia

Ozturk, Gokhan. 2016. Foreign Language Teaching Anxiety among Non-native Teachers of English: A Sample from Turkey. Sakarya University Journal of Education ss. 54-70.

Pasaribu, T. Almendo. 2018. English Language Anxiety Of Pre-Service Teachers: Causes And Coping Strategies. LLT Journal: A Journal On Language And Language Teaching

Tran, Trang Thi Tu. 2015. Management of Foreign Language Anxiety: Insiders' awareness and experiences. Tran \& Moni, Cogent Education (2015), 2:992593

Tum, Danyal Oztaz. 2012. Feelings Of Language Anxiety Amongst Non-Native Student Teachers. Procedia - Social and Behavioral Sciences 47 ( 2012 ) 2055 - 2059

Tuyen, Nguyen Van. 2017. Factors that Affect Students' Reticence in Class. Advances in Social Science, Education and Humanities Research, volume 115

Weiss, Ingrid. 2016. Becoming a Bilingual School: Perspectives of L2FLS Teachers \& Principals. Dissertation of University of Technology, Sydney.

Wuli, S. Fitriati. 2012. English Bilingual Education in an Indonesian Public School. Educational Innovations and Contemporary Technologies Palgrave Macmillan

Yoon, Tecnam. 2012. Teaching English Through English. Exploring Anxiety in Non-Native PreService ESL Teachers. Theory and Practice in Language Studies, Vol. 2, No. 6, pp. 10991107, June 2012 